\title{
Binding Studies of Ruthenium(II) Polypyridyl Complexes with Quinones in Triton X-100
}

\author{
T. SUMITHA CELIN and G. ALLEN GNANA RAJ ${ }^{*}$
}

Department of Chemistry and Research Centre, Scott Christian College (Autonomous) Nagercoil (Affiliated to Manonmaniam Sundaranar University, Abishekapatti, Tirunelveli) Tamilnadu- 629 003, India

allengraj@gmail.com

Received 3 May 2018 / Accepted 20 May 2018

\begin{abstract}
The binding of $\mathrm{Ru}(\mathrm{II})$ polypyridyl complexes $\left[\mathrm{Ru}(\mathrm{bpy})_{3}\right]^{2+},\left[\mathrm{Ru}(\mathrm{dmb} p \mathrm{~b})_{3}\right]^{2+}$ with 1,4-benzoquinone (BQ) and 2,6-dimethyl -1,4-benzoquinone (DMBQ) have been studied in triton $\mathrm{x}-100$ using absorption spectral technique. The binding constant $\left(\mathrm{K}_{\mathrm{b}}\right)$ for these reactions are determined from the Benesi-Hildebrand equation by means of absorption intensity data. Values of the binding constant reveal that they depend on the nature of the ligand, medium and also on the structure of the quinones. The ground state interaction between the luminophore and the quencher are hydrophobic in nature. Hydrophobic and structural effects play a vital role on the binding of the quinones with $\mathrm{Ru}(\mathrm{II})$ complexes.
\end{abstract}

Keywords: Binding, Quenching, Quinones, Ligands, Quenchers

\section{Introduction}

Quinones have considerate application in the field of biology and pharmacy. They are ET mediators between PSI and PSII and act as anticancer drugs in medicine ${ }^{1-7}$. They play an important role in the biochemistry of living cells. These quinones have a broad variety of pharmacological properties like antimicrobial, antiparasitic, antiviral and anticancer activities $^{8}$. Therefore the search for new chemotherapeutics focuses in metal complexes with different mode of action. The development of transition metal complexes is an emerging field in order to target and material with proteins, antioxidants, metal complexes of phenanthroline, bipyridine activity. Ruthenium complexes of various ligands have attracted great interest as alternative drugs to cisplatin in cancer therapy. The significant structural differences between ruthenium and most platinum have antitumour drugs give a promising alternative to cisplatin and carboplatin?. Among the transition metal complexes, ruthenium(II) polypyridyl complexes $\left[\mathrm{Ru}(\mathrm{NN})_{3}\right]^{2+}$ have particularly drawn significant interest to develop new therapeutic agents. They undergo binding with DNA, proteins, RNA. Based on the literature survey, the present study concentrates on the binding studies of quinones with $\mathrm{Ru}(\mathrm{II})$ complexes in Triton $\mathrm{x}-100$. 
The $\mathrm{Ru}(\mathrm{II})$ complexes have been used as probes in micellar medium and the properties vary with the nature of surfactant and the concentration. $\mathrm{Ru}(\mathrm{II})$ polypyridyl complexes have been designed with hydrophobic ligands and thus they provides an opportunity to bind to the initial interfacial region in micro heterogeneous systems. These aqueous micelle-bound catalytic systems are attractive alternatives to highly toxic, expensive organic solvents and precursors to future designs of surfactant assemblies that may include redox reactions in biological membranes. These organized micellar media can promote ET from electron donor to acceptor by concentrating them.

\section{Experimental}

$\mathrm{RuCl}_{3} \cdot 3 \mathrm{H}_{2} \mathrm{O}$, ligands (2,2'-bipyridine (bpy), 4,4'-dimethyl-2,2'-bipyridine (dmbpy), 4,4'-ditertiary butyl -2,2'-bipyridine (dtbpy)) and the quinones (1,4-benzoquinone (BQ), 2,6-dimethyl-1,4-benzoquinone (DMBQ)) were procured from Sigma -Aldrich. The double distilled deionized water was used for the binding studies. The three $\left[\mathrm{Ru}(\mathrm{NN})_{3}\right]^{2+}$ complexes \{where $\mathrm{NN}=2,2^{\prime}$-bipyridine (bpy), 4,4'-dimethyl-2,2'-bipyridine (dmbpy), 4,4'-ditertiary butyl-, 2'-bipyridine (dtbpy)] were synthesized by reacting $\mathrm{RuCl}_{3} \cdot \mathrm{H}_{2} \mathrm{O}$ with the corresponding ligands by the known procedures ${ }^{10-11}$.

Absorption spectral measurements were carried out using SYSTRONICS double beam spectrophotometer 2203. Quartz cuvettes with a path length of $1 \mathrm{~cm}$ were used throughout. The emission intensity measurements were recorded using JASCO/FP-8600 spectrofluorometer with a $1 \mathrm{~cm}$ path length quartz cell, equipped with a $150 \mathrm{~W}$ Xenon source, a red sensitive photomultiplier tube. The binding of $\left[\mathrm{Ru}(\mathrm{NN})_{3}\right]^{2+}$ complexes with various concentration $\left(4 \times 10^{-6} \mathrm{M}-2.8 \times 10^{-7} \mathrm{M}\right)$ of $\mathrm{BQ}$, MBQ, DMBQ have been studied by absorption spectral technique. All the sample solutions were freshly prepared. The binding constant $\left(\mathrm{k}_{\mathrm{b}}\right)$ of the $\mathrm{Ru}(\mathrm{II})$ complexes with quinones were determined from the BenesiHildebrand equation using the absorption intensity data.

$$
\frac{1}{\Delta A}=1 / k_{b} \Delta \in \varepsilon[H]+\frac{1}{\Delta \varepsilon}[Q]
$$

Where $\Delta \mathrm{A}$ is the change in absorption of the complex with different concentrations ([Q]) of the quinones. The plots of $1 / \Delta A$ verses $1 /[Q]$ gives a straight line. The binding constant $\mathrm{k}_{\mathrm{b}}$ is got from the ratio of $Y$-intercept to the slope of the straight line.

\section{Results and Discussion}

The structure of the ligands and the quinones used in the presence study are shown in Figure 1. The photophysical properties like absorption and emission spectral data and excited state lifetimes of $\left[\mathrm{Ru}(\mathrm{NN})_{3}\right]^{2+}$ complexes in aqueous and triton $\mathrm{x}-100$ are given in Table 1 . The photophysical properties of the $\left[\mathrm{Ru}(\mathrm{NN})_{3}\right]^{2+}$ complexes change from homogeneous to micro heterogeneous medium.

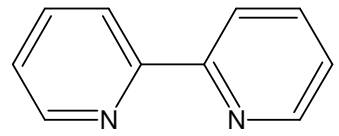

bpy

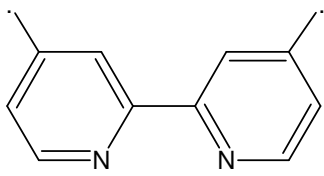

dmbpy

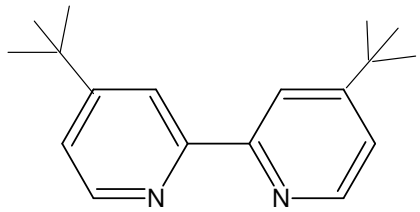

dtbpy 
<smiles>O=C1C=CC(=O)C=C1</smiles>

1,4-benzoquinone<smiles>CC1=CC(=O)C=C(C)C1=O</smiles>

2,6-dimethyl-1,4-benzoquinone

Figure. 1 Structure of ligands and quenchers

Table 1. Absorption, emission spectral data and excited state lifetime of $\left[\mathrm{Ru}(\mathrm{NN})_{3}\right]^{2+}$ complexes in aqueous and triton $\mathrm{x}-100^{12}$

\begin{tabular}{ccccccc}
\hline \multirow{2}{*}{ Complex } & \multicolumn{2}{c}{$\begin{array}{c}\text { Absorption } \\
\text { maximum, nm }\end{array}$} & \multicolumn{2}{c}{$\begin{array}{c}\text { Emission } \\
\text { maximum, nm }\end{array}$} & \multicolumn{2}{c}{$\begin{array}{c}\text { Excited state } \\
\text { lifetime }(\mathrm{ns})\end{array}$} \\
\cline { 2 - 7 } & aqueous & $\begin{array}{c}\text { Triton } \\
\mathrm{x}-100\end{array}$ & aqueous & $\begin{array}{c}\text { Triton } \\
\mathrm{x}-100\end{array}$ & aqueous & $\begin{array}{c}\text { Triton } \\
\mathrm{x}-100\end{array}$ \\
\hline$\left[\mathrm{Ru}(\mathrm{bpy})_{3}\right]^{2+}$ & 448 & 451 & 595 & 595 & 614 & 600 \\
{$\left[\mathrm{Ru}(\mathrm{dmbpy})_{3}\right]^{2+}$} & 458 & 458 & 604 & 615 & 380 & 360 \\
{$\left[\mathrm{Ru}(\mathrm{dtbpy})_{3}\right]^{2+}$} & 457 & 465 & 610 & 617 & 510 & 654 \\
\hline
\end{tabular}

The absorption spectral studies of the $\left[\mathrm{Ru}(\mathrm{NN})_{3}\right]^{2+}$ complexes show a slight increase in the MLCT absorption maximum with incremental addition of the quinones. This mediate the formation of ground state complex (Figure 2). The binding constant $\left(\mathrm{k}_{\mathrm{b}}\right)$ of $\left[\mathrm{Ru}(\mathrm{NN})_{3}\right]^{2+}$ complexes with the quinones calculated from the Benesi-Hildebrand plot (Figure 3 ) for the absorption spectral date and emission spectral data in triton $\mathrm{x}-100$ medium is given in Table 2. The $\mathrm{k}_{\mathrm{b}}$ values obtained for the quinones with $\left[\mathrm{Ru}(\mathrm{NN})_{3}\right]^{2+}$ are in the complexes order of $10^{3}$ to $10^{4}$.

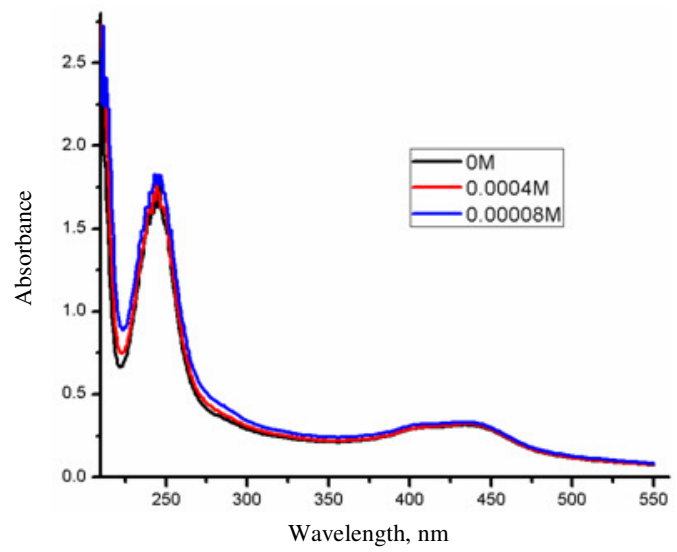

Figure 2. Absorption spectrum of $\left[\mathrm{Ru}(\mathrm{bpy})_{3}\right]^{2+}$ with incremental concentration of 1,4-benzoquinone in triton $\mathrm{x}-100$.

Table 2. Binding constant, $\mathrm{k}_{\mathrm{b}}\left[\mathrm{M}^{-1}\right]$ from absorption and emission data for the quinones with $\left[\mathrm{Ru}(\mathrm{NN})_{3}\right]^{2+}$ in Triton $\mathrm{x}-100$

\begin{tabular}{ccccc}
\hline \multirow{2}{*}{ Complex } & \multicolumn{2}{c}{ Absorption data } & \multicolumn{2}{c}{ Emission date } \\
\cline { 2 - 5 } & BQ & DMBQ & BQ & DMBQ \\
\hline$\left[\mathrm{Ru}(\mathrm{bpy})_{3}\right]^{2+}$ & $5.59 \times 10^{4}$ & $9.13 \times 10^{4}$ & $3.42 \times 10^{4}$ & $3.47 \times 10^{4}$ \\
{$\left[\mathrm{Ru}(\mathrm{dmbpy})_{3}\right]^{2+}$} & $6.35 \times 10^{4}$ & $7.11 \times 10^{4}$ & $1.8 \times 10^{4}$ & $1.96 \times 10^{4}$ \\
\hline
\end{tabular}




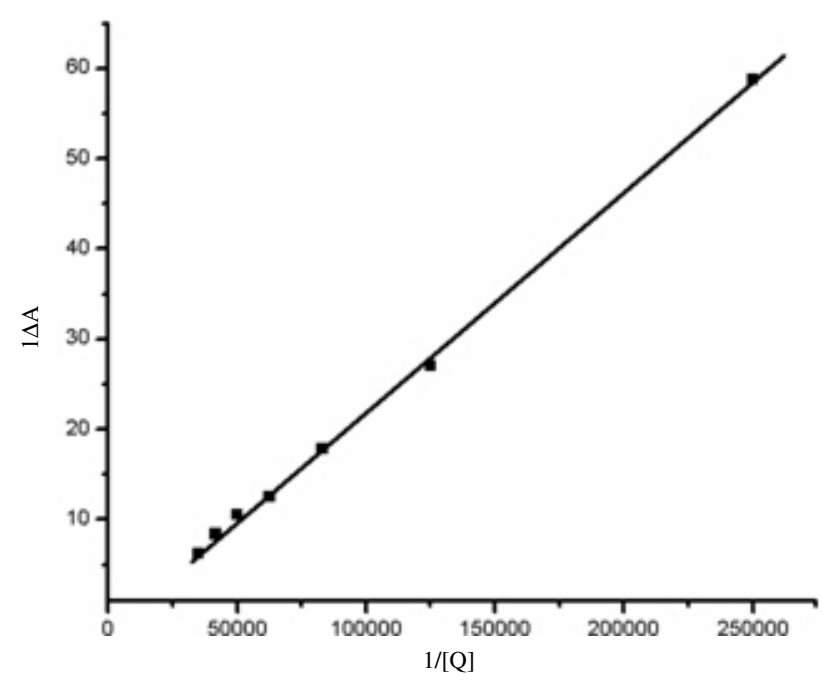

Figure 3. Benesi-Hildebrand plot on MLCT absorption of $\left[\mathrm{Ru}(\mathrm{bpy})_{3}\right]^{2+}$ complex with incremental addition of BMBQ in triton $\mathrm{x}-100$ medium

The addition of the neutral surfactant triton $\mathrm{x}-100$ resulted in the red shift to the tune of 3-8 $\mathrm{nm}$ for the absorption maximum. The ground state interaction between uinines and the bipyridyl rings of the luminophore are hydrophobic or $\pi$-stacking in nature. Binding becomes stronger due to $\pi-\pi$ stacking interaction. The hydrophobicity increases from $\left[\mathrm{Ru}(\mathrm{bpy})_{3}\right]^{2+}$ to $\left[\mathrm{Ru}(\mathrm{dtbpy})_{3}\right\}^{2+}$. It is due to the presence of bulky alkyl to substituted ligands. $\mathrm{K}_{\mathrm{b}}$ value increases with the increase in hydrophobicity. This result shows that $\mathrm{k}_{\mathrm{b}}$ values are sensitive to the hydrophobic nature of the ligands.

It is seen that $K_{b}$ values increases when the substituent in the 1,4-benzoquinone is changed. On moving from BQ to DMBQ, the size increases. The $\mathrm{k}_{\mathrm{b}}$ value also shows an increase. This result shows that $\mathrm{k}_{\mathrm{b}}$ is value is also sensitive to the structure of the uinines. Thus we find the $\mathrm{k}_{\mathrm{b}}$ values are sensitive to the nature of the ligand, medium and structure of the quenches 1,4-benzoquinone and 2,6-dimethyl-1,4-benzoquinone.

\section{Conclusion}

The binding of 1,4-benzoquinone and 2,6-dimethyl-1,4-benzoquinone with $\left[\mathrm{Ru}(\mathrm{NN})_{3}\right]^{2+}$ complexes in triton $\mathrm{x}-100$ has been studied by absorption spectral techniques. The $\mathrm{k}_{\mathrm{b}}$ values of the $\left[\mathrm{Ru}(\mathrm{NN})_{3}\right]^{2+}$ complexes with 1,4-benzoquinone and 2,6-dimethyl-1, 4-benzoquinone are determined from the Benesi-Hildebrand plot. The $k_{b}$ values depend on the nature of the ligand medium as well as the structure of uinines. 2,6-dimethyl-1,4-benzoquinone shows high binding constant compared to 1,4-benzoquinone. This may be attributed due to the structural change. The study confirms the structural effects, hydrophobicity as well as the effect of medium on the binding of uinines with $\left[\mathrm{Ru}(\mathrm{NN})_{3}\right]^{2+}$.

\section{References}

1. Paulpandian Muthu Mareeswaran, Eswaran Rajkumar, Veerasamy Sathish and Seenivasan Rajagopal, Luminescence, 2013, 26(2), 754-761; DOI:10.1002/bio.2617

2. Gomer H, J Photochem Photobiol B Biol., 2007, 88(2-3), 83-89; DOI:10.1016/j.jphotobiol.2007.05.003 
3. Gomer H, Photochem Photobiol Sci., 2004, 3, 933-938; DOI:10.1039/B410386F

4. Giacco T D, Elisel F and Lanzalunga O, Phys Chem Chem Phys., 2000, 2, 1701-1708; DOI:10.1039/A909372I

5. Easka Y, Okumura N, Uno B and Goto M, Anal Sci., 2001, 17(1), 99-102; DOI:10.2116/analsci.17.99

6. Pochon A, Vaughan P P, Gan D, Vath P, Blough N V and Falvey D E, J Phys Chem A., 2002, 106(12), 2889-2894; DOI:10.1021/jp012856b

7. Barbara P F, Meyer T J and Ratner M A, J Phys Chem., 1996, 100(31), 13148-13168; DOI:10.1021/jp9605663

8. Mario Kubanik, Wolfgang Kandioller, Kunwoo kim, Robert F Anderson, Erik Klapproth, Micheal A Jakupec, Alexander Roller, Tilo Sohnel, Bernhard . Keppler and Christian G Hartinger, Dalton Trans., 2016, 45, 13091-13103; DOI:10.1039/C6DT01110A

9. Kiruthika M, Elayaperumal R and Vennila T, Int J ChemTech Res., 2013, 5(4), 1839-1846.

10. Connors K A, "Binding Constants: The measurement of Stability", John Wiley and Sons, Ltd Chichester, U. K., 1987.

11. Swarnalatha K and Sornalatha S, Int J Adv Res., 2016, 4(2), 235-241.

12. G Allen Gnana Raj, Green Chem Technol Lett., 2015, 1(1), 77-81. 